\title{
Keterlibatan Orang Tua terhadap Keterampilan Sosial Siswa Berkebutuhan Khusus di Sekolah Dasar Inklusif
}

\author{
Parents Involvement in Social Skills of Students \\ with Special Educational Need in Inclusive Elementary Schools
}

\author{
Frieda Maryam Mangunsong ${ }^{1}$ E Citra Wahyuni \\ 1,2Fakultas Psikologi Universitas Indonesia
}

\begin{abstract}
This study aims to examine the relationship between parental involvement and social skills of students with SEN in inclusive elementary primary. It also examines student factors, namely gender, types of disability, and level of impairment that can affect student's social skills. Participants were 365 parents of students with Special Educational Need (SEN) in inclusive elementary school. Parental involvement was measured using the Family Involvement Questionnaire. Students' social skills assessed using the Social Skills Improvement System. This research uses quantitative method and correlational nonexperimental design. The results showed that parents' involvement was significantly related to the social skills of students with SEN. It means that the more parents are involved in the education, the higher the social skills of the children will have. In regards to demographic variables, only gender of children that can affect children's social skills.
\end{abstract}

Keywords: inclusive education; parental involvement; social skills

Abstrak. Penelitian ini bertujuan untuk menguji hubungan antara keterlibatan orang tua dan keterampilan sosial siswa berkebutuhan khusus di sekolah dasar inklusif. Juga menguji faktor siswa seperti jenis kelamin, jenis dan tingkat hambatan yang dialami siswa terhadap keterampilan sosial yang dimilikinya. Partisipan dalam penelitian ini sebanyak 365 orang tua dari siswa berkebutuhan khusus di sekolah dasar inklusif. Keterlibatan orang tua diukur dengan menggunakan Family Involvement Questionnaire. Keterampilan sosial siswa dinilai dengan menggunakan Social Skills Improvement System. Penelitian ini menggunakan metode kuantitatif dan desain non-eksperimental korelasional. Hasil penelitian menunjukkan bahwa keterlibatan orang tua berhubungan signifikan dengan keterampilan siswa berkebutuhan khusus. Semakin orang tua terlibat dalam proses pendidikan, maka semakin tinggi keterampilan sosial yang dimiliki oleh anak. Berkaitan dengan variabel demografi, hasil penelitian menunjukkan bahwa hanya jenis kelamin siswa yang dapat memengaruhi keterampilan sosial siswa berkebutuhan khusus.

Kata kunci: keterlibatan orang tua; keterampilan sosial; pendidikan inklusif

Pendidikan inklusif merupakan suatu tren baru di dunia pendidikan yang berangkat dari perspektif sosial disabilitas dan keadilan sosial. Pendidikan inklusif menekankan proses pembelajaran yang berkualitas dan tidak memiliki batas. Semua siswa termasuk siswa berkebutuhan khusus berhak mengikuti semua pelajaran

\footnotetext{
${ }^{1}$ Korespondensi mengenai artikel ini dapat melalui: friemangun@gmail.com; atau citrawahyuni16@gmail.com
} 
yang ada di kurikulum reguler sebagai suatu cara menemukan, memenuhi, dan mengoptimalkan kemampuannya (Booth \& Ainscow, 2002).

Penerapan pendidikan inklusif di Indonesia dimulai sejak tahun 2002 melalui pelaksanaan proyek uji coba di sembilan provinsi yang memiliki pusat sumber dan berhasil mewujudkan 1500 siswa berkebutuhan khusus untuk belajar di sekolah reguler. Pada tahun 2016, terdapat $18 \%$ siswa berkebutuhan khusus yang belajar di sekolah inklusif (Kementerian Pendidikan dan Kebudayaan, 2017). Selain itu menurut Data Dinas Pendidikan DKI Jakarta tahun 2016, terdapat 257 penyelenggara sekolah dasar negeri inklusif di DKI Jakarta. Berdasarkan angka partisipasi siswa berkebutuhan khusus di sekolah inklusif yang terus meningkat dan jumlah sekolah inklusif yang paling banyak ada di jenjang sekolah dasar, dapat disimpulkan bahwa angka partisipasi siswa berkebutuhan khusus di sekolah dasar inklusif cukup tinggi terutama di Provinsi DKI Jakarta.

Beberapa hasil penelitian menunjukkan bahwa siswa berkebutuhan khusus di sekolah dasar inklusif lebih mendapatkan manfaat secara akademis dibandingkan siswa berkebutuhan khusus di sekolah dasar luar biasa (Dessemontet, Bless, \& Morin, 2012; Szumski \& Karwowski, 2014). Akan tetapi, hasil penelitian Leyser dan Kirk (2004) menunjukkan bahwa keterlibatan sosial merupakan motif orang tua siswa berkebutuhan khusus memasukkan anak mereka ke sekolah inklusif. Orang tua menganggap bahwa siswa berkebutuhan khusus dapat terlibat aktif dalam kegiatan akademik dan non akademik dengan siswa reguler dimana hal tersebut penting bagi kehidupan mereka di masa depan. Hal tersebut sesuai dengan kunci pendidikan inklusif yang menitikberatkan pada kesempatan siswa berkebutuhan khusus untuk menjadi bagian dari peer-group, membentuk hubungan sosial yang positif, menjalin pertemanan dan persahabatan dengan siswa lainnya (Flem \& Keller, 2000; Odom, Buysse, \& Soukakou, 2011; Peters, 2007).

Harapan agar siswa berkebutuhan khusus dapat terlibat secara sosial belum sepenuhnya dapat diwujudkan. Hasil penelitian Rotheram-Fuller, Kasari, Chamberlain, dan Locke (2010) pada 79 siswa dengan Autistic Spectrum Disorder (ASD) di sekolah dasar inklusif di Los Angeles, Amerika Serikat menunjukkan bahwa siswa ASD kurang diterima oleh siswa reguler dan hanya sedikit memiliki hubungan pertemanan dengan siswa reguler. Lebih lanjut, hasil penelitian Krull, Wilbert, dan Hennemenn (2014) juga menunjukkan bahwa siswa berkebutuhan khusus yang mengalami kesulitan belajar dan siswa yang mengalami gangguan tingkah laku mendapati situasi sosial dan emosional yang tidak menyenangkan di kelas mereka. Siswa berkebutuhan khusus ditolak sebagai teman sebangku di kelas, mengalami perlakuan tidak menyenangkan dari teman-teman mereka di kelas, dan kurang diterima oleh guru mereka. Penelitian ini dilakukan pada 256 orang siswa berkebutuhan khusus yang mengalami kesulitan belajar dan gangguan tinglah laku di 64 sekolah dasar inklusif di Jerman.

Di Indonesia, hasil penelitian Aini (2008) pada enam orang siswa yang mengalami autis menunjukkan hal yang serupa. Siswa dengan autisme sering diabaikan oleh teman-temannya, ditolak untuk bergabung dalam kelompok, serta sering dijahili dan diganggu oleh siswa reguler. Kondisi yang terjadi di luar Indonesia dan di Indonesia tersebut tidak sesuai dengan filosofi pendidikan inklusif, 
dimana salah satu komponen kesuksesan dari pendidikan inklusif adalah siswa berkebutuhan khusus merasa menjadi bagian dari pendidikan sekolah umum (National Association of Special Education Teachers, 2004).

Salah satu keterampilan yang dibutuhkan anak dalam membangun hubungan positif dengan teman sebayanya adalah keterampilan sosial (Gresham \& Elliott, 1990). Keterampilan sosial adalah sejumlah tingkah laku yang dipelajari dan ditunjukkan oleh individu sebagai suatu kinerja dalam berinteraksi dengan orang lain pada lingkungan tertentu. Adapun dimensi dari keterampilan sosial adalah komunikasi, kerja sama, asertif, tanggung jawab, empati, keikutsertaan, dan kontrol diri (Gresham \& Elliott, 2008). Keterampilan sosial merupakan hal yang penting untuk dikembangkan dan dibentuk pada siswa di tingkat pendidikan dasar, di mana pada usia sekolah dasar ini siswa mulai beradaptasi dengan lingkungan pembelajaran yang memungkinkannya untuk berinteraksi lebih sering dengan teman sebaya dan guru di sekolah (RimmKaufman, Curby, Grimm, Brock, \& Nathanson, 2009).

Selama bertahun-tahun, banyak literatur yang telah mendokumentasikan peran orang tua dan keluarga dalam mengembangkan keterampilan sosial anak. Dari penelitian-penelitian sebelumnya terdapat bukti bahwa karakteristik keluarga, terutama keterlibatan orang tua (parental involvement) berpengaruh secara langsung terhadap keterampilan sosial anak (Powell, Son, \& File, 2010; Nokali, Bachman, \& Votruba-Drzal, 2010; McWayne, Fantuzzo, \& McDermott, 2004). Keterlibatan orang tua dalam penelitian ini adalah tingkah laku yang ditunjukkan orang tua yang termanifestasi ke dalam tiga domain keterlibatan orang tua, yakni keterlibatan orang tua di sekolah, di rumah, dan hubungan antara rumah dan sekolah (Fantuzzo,Tighe, \& Childs, 2000).

Pada konteks siswa berkebutuhan khusus, keterlibatan orang tua dapat membantu siswa berkebutuhan khusus mempelajari dan menunjukkan keterampilan sosial yang tepat dan dibutuhkan dalam berinteraksi dengan orang lain di lingkungan tertentu, termasuk lingkungan sekolah. Orang tua dapat mengajarkan keterampilan sosial melalui pemberian contoh tingkah laku yang tepat ketika berinteraksi dengan orang lain maupun dengan siswa berkebutuhan khusus itu sendiri. Melalui keterlibatan orang tua, siswa dapat mempelajari cara merespon tingkah laku dan menunjukkan tingkah laku yang tepat ketika berinteraksi dengan orang lain (Cartledge \& Milburn, 1995).

Beberapa penelitian mengenai keterlibatan orang tua terhadap keterampilan sosial siswa berkebutuhan khusus hasilnya masih berbeda. Penelitian Epley (2009) menunjukkan hasil bahwa keterlibatan orang tua berhubungan signifikan dengan keterampilan sosial 157 siswa berkebutuhan khusus yang berusia lima sampai enam tahun. Bertentangan dengan hal tersebut, penelitian Bennett dan Hay (2007) justru menunjukkan bahwa keterlibatan orang tua tidak berhubungan secara signifikan dengan keterampilan sosial siswa berkebutuhan khusus. Penelitian ini dilakukan pada 212 siswa berkebutuhan khusus yang berusia lima sampai 12 tahun di sekolah umum di Australia.

Hasil penelitian yang berkaitan dengan keterampilan sosial menunjukkan bahwa terdapat beberapa faktor yang berpengaruh, yaitu jenis kelamin, jenis hambatan yang dialami anak, dan tingkat hambatan yang dialami anak. Khususnya pada anak berkebutuhan khusus hasilnya menunjukkan bahwa anak perempuan 
secara umum menunjukkan keterampilan sosial yang lebih baik dibanding anak lakilaki (Epley, 2009).

Faktor jenis hambatan yang dialami anak, dapat memengaruhi perkembangan keterampilan sosialnya. Anak yang mengalami cognitive deficit mempunyai ketidakmampuan dalam menunjukkan tingkah laku yang diinginkan. Untuk anak yang mengalami behavioral deficit, perilakunya cenderung agresif. Hal ini dikarenakan mereka kurang mampu memahami isyarat-isyarat yang ada di lingkungan dan dalam membentuk solusi bagi masalah yang dihadapinya. Akan tetapi, berdasarkan beberapa penelitian yang berkaitan dengan keterampilan sosial pada anak berkebutuhan khusus, pengaruh faktor jenis hambatan terhadap keterampilan sosial masih mengalami perdebatan. Hasil penelitian Macintosh dan Dissanayake (2006) menunjukkan bahwa tidak ada perbedaan skor keterampilan sosial antara siswa yang mengalami High-Functioning Autism (HFA) dan siswa yang mengalami Asperger's Disorder (AsD). Hasil penelitian Lane, Carter, Pierson, dan Glaeser (2006) justru menunjukkan bahwa siswa dengan gangguan emosi memiliki keterampilan sosial yang lebih rendah dibandingkan siswa yang mengalami kesulitan belajar.

Menurut Gresham dan Elliott (2008) tingkat hambatan yang dialami anak berpengaruh positif dengan keterampilan sosial yang dimilikinya. Anak dengan tingkat hambatan parah atau severe cenderung tidak dapat mempelajari keterampilan sosial yang ada di masyarakat. Akan tetapi, hasil penelitian Bennett dan Hay (2007) menunjukkan bahwa tidak ada hubungan yang signifikan antara keparahan disabilitas yang dialami anak dengan keterampilan sosial yang dimilikinya ( $r=-.05, \mathrm{p}>.05)$ (Bennett \& Hay, 2007).

Berdasarkan penjabaran mengenai keterampilan sosial dan keterlibatan orang tua, penelitian ini dilakukan dengan tujuan untuk: 1) Menguji hubungan antara keterlibatan orang tua dan keterampilan sosial siswa berkebutuhan khusus di sekolah dasar inklusif, dan 2) Menguji hubungan antara faktor jenis kelamin, jenis hambatan, dan tingkat hambatan dengan keterampilan sosial siswa berkebutuhan khusus di sekolah dasar inklusif.

\section{Metode}

\section{Partisipan}

Partisipan $(N=365)$ dalam penelitian ini adalah orang tua dari siswa berkebutuhan khusus yang belajar di 17 sekolah dasar negeri inklusif dan lima sekolah dasar swasta inklusif di lima wilayah Kota DKI Jakarta. Partisipan dalam penelitian ini diperoleh dengan teknik convenience sampling, yakni berdasarkan kesediaan partisipan untuk mengikuti penelitian ini. Sebagian besar orang tua yang mengikuti penelitian ini $80,50 \%$ ibu $(n=294)$ dan sebagian besar orang tua berasal dari kelompok status sosial-ekonomi menengah ke bawah, yakni sebanyak 53,70\% $(n=196)$. Pengelompokan status sosial-ekonomi didasarkan pada pendapatan orang tua dalam kaitannya mengeluarkan uang untuk membeli dan membayar hal-hal yang penting, seperti makanan, kontrak atau sewa rumah, pembayaran rekening pendidikan anak atau perawatan kesehatan (Sanders \& Morawska, 2010). Penjelasan lebih rinci mengenai karakteristik orang tua akan dijabarkan pada Tabel 1. 
Tabel 1

Karakteristik orang tua $(\mathrm{N}=365)$

\begin{tabular}{|c|c|c|c|}
\hline Variabel Demografi & & $N$ & $\%$ \\
\hline \multirow[t]{2}{*}{ Jenis Kelamin } & Laki-laki & 71 & 19,50 \\
\hline & Perempuan & 294 & 80,50 \\
\hline \multirow[t]{6}{*}{ Pendidikan } & SD & 44 & 12,10 \\
\hline & SMP & 52 & 14,20 \\
\hline & SMA & 153 & 41,90 \\
\hline & Diploma & 38 & 10,40 \\
\hline & S1 & 72 & 19,70 \\
\hline & S2 & 6 & 1,60 \\
\hline \multirow[t]{2}{*}{ Status pernikahan } & Menikah & 332 & 91 \\
\hline & Bercerai & 33 & 9 \\
\hline \multirow[t]{2}{*}{ Status sosial-ekonomi } & Menengah Ke Bawah & 196 & 53,70 \\
\hline & Menengah Ke Atas & 169 & 46,30 \\
\hline \multirow[t]{5}{*}{ Jumlah anak dalam keluarga } & 1 anak & 44 & 12,10 \\
\hline & 2 anak & 170 & 46,60 \\
\hline & 3 anak & 87 & 23,80 \\
\hline & 4 anak & 39 & 10,70 \\
\hline & Lebih dari 4 anak & 25 & 6,80 \\
\hline
\end{tabular}

Sebagian besar siswa berkebutuhan khusus yang dinilai dalam penelitian ini adalah laki-laki yakni sebesar 69,90\% $(n=$ 255) dan perempuan sebanyak $30,10 \%$ ( $n=$ 110). Peneliti membagi klasifikasi tingkat hambatan yang dialami siswa berkebutuhan khusus berdasarkan AAMR Ad Hoc on Terminology and Classification (Mangunsong, 2014). Siswa berkebutuhan khusus yang memiliki tingkat hambatan ringan adalah siswa yang sedikit memerlukan bantuan pada kegiatan tertentu yang dilakukannya, sedangkan yang memiliki tingkat hambatan sedang adalah siswa yang memerlukan bantuan pada sebagian besar kegiatan yang dilakukannya. Terakhir, siswa berkebutuhan khusus dengan tingkat hambatan berat, memerlukan bantuan secara terus menerus dan intensif pada setiap kegiatan yang dilakukannya. Gambaran karakteristik siswa berkebutuhan khusus dalam penelitian ini akan dijabarkan secara rinci pada Tabel 2.

\section{Alat ukur}

Penelitian ini menggunakan alat ukur Family Involvement Questionnaire (FIQ) yang dikembangkan oleh Fantuzzo et al. (2000) untuk mengukur keterlibatan orang tua, dan Social Skills Improvement System (SSIS) yang dikembangkan Gresham dan Elliott (2008) untuk keterampilan sosial siswa. Alat ukur FIQ terdiri dari tiga dimensi dan 24 aitem, yaitu keterlibatan orang tua di sekolah (enam aitem), keterlibatan orang tua di rumah (11 aitem), dan hubungan antara rumah dan sekolah (tujuh aitem). Keterlibatan orang tua di sekolah mengukur tingkah laku yang ditunjukkan orang tua dalam berbagai kegiatan di sekolah anak (Contoh aitem: "Saya jarang hadir ketika ada undangan dari sekolah terkait pendidikan anak saya"). 
Tabel 2

Karakteristik siswa berkebutuhan khusus $(\mathrm{N}=365)$

\begin{tabular}{llcc}
\hline Variabel Demografi & & $N$ & $\%$ \\
\hline Jenis Kelamin & Laki-laki & 255 & 69,90 \\
& Perempuan & 110 & 30,10 \\
& Tunanetra & 2 & 0,50 \\
& Tunarungu & 14 & 3,80 \\
& Tunawicara & 2 & 0,50 \\
& Tunagrahita & 103 & 28,20 \\
& Down Syndrome & 3 & 0,80 \\
& Lamban Belajar & 101 & 27,70 \\
& Kesulitan Belajar & 11 & 3 \\
& Tunadaksa & 15 & 4,10 \\
& Gangguan Emosi dan Tingkah & 3 & 0,80 \\
& Laku & 31 & 8,50 \\
& Autis & 19 & 5,20 \\
& ADHD & 61 & 16,70 \\
& Lebih dari satu hambatan & & \\
Tingkat Hambatan & Ringan & 179 & 49 \\
& Sedang & 145 & 39,80 \\
& Berat & 41 & 11,20 \\
\hline
\end{tabular}

Keterlibatan orang tua di rumah mengukur tingkah laku mereka dalam menciptakan lingkungan pembelajaran yang mendukung bagi anak (Contoh aitem: "Saya berusaha menyediakan peralatan sekolah yang dibutuhkan anak saya untuk belajar"). Hubungan antara rumah dan sekolah mengukur komunikasi yang terjalin antara orang tua dengan pihak sekolah mengenai perkembangan anak (Contoh aitem: "Saya berkomunikasi dengan guru anak saya tentang kesulitankesulitan anak saya di sekolah").

Alat ukur FIQ ini telah diuji reliabilitasnya dan mendapatkan nilai koefisien reliabilitas yang baik $\propto=0,84$. Alat ukur FIQ juga telah diuji validitasnya dengan menggunakan CFA dan didapat nilai factor loading tiap item yang berkisar antara 0,360,75 . Alat ukur FIQ juga memiliki indikator fit yang baik, yaitu $\left(\chi^{2}=329,80 ; d f=179, p<\right.$ 0.001 , RMSEA $=0,048$, GFI = 0,93).
Alat ukur FIQ menggunakan respon jawaban 1-4 dengan midpoint untuk alat ukur ini adalah 2,5. Nilai midpoint 2,5 menjadi patokan dalam menginterpretasikan data dari keterlibatan orang tua. Orang tua siswa berkebutuhan khusus menunjukkan keterlibatan yang rendah jika memiliki nilai mean $<2,5$; dan menunjukkan keterlibatan yang tinggi jika memiliki mean $>2,5$.

SSIS terdiri dari tujuh dimensi dan 43 aitem, yaitu komunikasi (enam aitem), kerja sama (enam aitem), asertif (tujuh aitem), tanggung jawab (enam aitem), empati (enam aitem), keikutsertaan (enam aitem), dan kontrol diri (enam aitem). Alat ukur ini telah diuji reliabilitasnya dan mendapatkan nilai koefisien reliabilitas yang baik $\propto=0,82$. Alat ukur ini juga telah diuji validitasnya dengan menggunakan CFA dan didapat nilai factor loading tiap aitem yang berkisar antara $0,30-0,78$ dan 
memiliki indikator fit yang baik, yaitu $\left(\chi^{2}=\right.$ 1243,05; $d f=675, p<0.001$, RMSEA= 0.048, $\mathrm{GFI}=0.86$ ).

Alat ukur SSIS yang diisi oleh orang tua menggunakan respon jawaban 0-3 dengan midpoint untuk alat ukur ini adalah 1,5. Nilai midpoint 1,5 menjadi patokan dalam menginterpretasikan data dari keterampilan sosial siswa yang dinilai oleh orang tua. Siswa berkebutuhan khusus dikatakan memiliki keterampilan sosial yang rendah jika memiliki nilai mean $<1,5$; dan memiliki keterampilan sosial yang tinggi jika memiliki mean $>1,5$.

\section{Prosedur}

Penelitian ini menggunakan metode kuantitatif dan desain korelasional, dengan keterlibatan orang tua sebagai variabel independen dan keterampilan sosial sebagai variabel dependen. Data dikumpulkan melalui kuesioner self-report dan menggunakan korelasi Pearson sebagai analisis statistik. Teknik pengambilan sampel yang digunakan dalam penelitian ini adalah convenience sampling, yakni peneliti memperoleh partisipan berdasarkan kesediaan dan keinginan partisipan untuk mengikuti penelitian. Proses pengambilan sampel dilakukan dengan mendatangi sekolah inklusif yang bersedia untuk diambil datanya. Selanjutnya peneliti mengambil data pada orang tua yang bersedia untuk mengisi kuesioner.

Sebelum melakukan penyebaran kuesioner, peneliti melakukan adaptasi alat ukur SSIS dengan mengacu pada tahapan yang dijelaskan oleh Beaton, Bombardier, Guillemin, dan Ferraz (2000). Alat ukur FIQ yang diisi oleh orang tua telah diadaptasi ke dalam bahasa Indonesia, sehingga peneliti tidak perlu melakukan adaptasi ulang. Akan tetapi, peneliti tetap melakukan uji validitas dan reliabilitas alat ukur FIQ dikarenakan sampel yang digunakan dalam penelitian ini berbeda dengan sampel yang digunakan dalam penelitian sebelumnya. Peneliti juga melakukan expert judgment kepada tiga dosen Psikologi Pendidikan dan melakukan uji keterbacaan pada dua orang tua dengan anak usia sekolah dasar, serta mengajukan persetujuan etik ke Fakultas Psikologi Universitas Indonesia.

Setelah persetujuan etik didapatkan, peneliti melakukan uji coba alat ukur yang dilakukan pada tiga sekolah dasar negeri inklusif di Lebak Bulus, dengan menyebarkan 50 kuesioner. Kuesioner-kuesioner tersebut tidak semuanya dapat diolah dimana terdapat kuesioner yang tidak diisi secara lengkap oleh orang tua, sehingga didapatkan 42 kuesioner orang tua yang dapat diolah dalam penelitian.

\section{Hasil}

Pada bagian ini akan dijelaskan hasil penelitian yang terdiri dari statistik deskriptif dari setiap variabel (Tabel 3 dan 4), korelasi antar dimensi variabel (Tabel 5), dan faktor yang memengaruhi keterampilan sosial siswa.

Tabel 3

Gambaran keterlibatan orang tua $(\mathrm{N}=365)$

\begin{tabular}{lcccc}
\hline Dimensi keterlibatan orang tua & $M$ & $S D$ & $\begin{array}{c}\text { Score } \\
\text { Minimum }\end{array}$ & $\begin{array}{c}\text { Score } \\
\text { Maximum }\end{array}$ \\
\hline Keterlibatan orang tua di sekolah & 2,90 & 0,43 & 1,00 & 4,00 \\
Keterlibatan orang tua di rumah & 3,14 & 0,40 & 1,00 & 4,00 \\
Hubungan rumah dan sekolah & 2,98 & 0,45 & 1,00 & 4,00 \\
\hline
\end{tabular}


Berdasarkan Tabel 3, skor rata-rata keterlibatan orang tua yang terbagi ke dalam dimensi keterlibatan orang tua di sekolah, di rumah dan dimensi hubungan rumah dan sekolah berada di atas nilai midpoint skala. Hasil ini menunjukkan bahwa keterlibatan orang tua pada pendidikan siswa berkebutuhan khusus cenderung tinggi. Dapat dikatakan bahwa orang tua dari siswa berkebutuhan khusus terlibat dalam kegiatan-kegiatan anak di sekolah, memberikan dukungan dan lingkungan belajar yang mendukung di rumah, serta berkomunikasi dengan pihak sekolah untuk membahas kemajuan belajar anak.

Berdasarkan Tabel 4, skor rata-rata keterampilan sosial siswa berkebutuhan khusus bervariasi pada masing-masing dimensi. Siswa berkebutuhan khusus mendapatkan skor rata-rata yang tinggi pada dimensi komunikasi, kerja sama, asertif, tanggung jawab, empati, dan keikutsertaan. Akan tetapi, siswa berkebutuhan khusus mendapatkan skor ratarata yang rendah pada dimensi kontrol diri $(M=1,42, S D=0,57)$. Hasil ini menunjukkan bahwa siswa berkebutuhan khusus cenderung memiliki keterampilan sosial yang tinggi. Hasil ini didapatkan dari pengamatan orang tua pada tingkah laku siswa berkebutuhan khusus selama dua bulan terakhir. Pengamatan selama dua bulan terakhir mengacu pada manual alat ukur SSIS.

Keterlibatan orang tua berkorelasi positif dan signifikan dengan keterampilan sosial siswa dengan $r=0,31 ; \mathrm{p}<0,01$. Hasil ini mengindikasikan bahwa semakin tinggi keterlibatan orang tua maka semakin tinggi keterampilan sosial siswa. Keterlibatan orang tua pada pendidikan anak secara positif dan signifikan berhubungan dengan keterampilan sosial anak sehari-hari berdasarkan pengamatan orang tua. Korelasi antar dimensi keterlibatan orang tua dengan dimensi keterampilan sosial siswa akan dijabarkan pada Tabel 5 di bawah ini.

Peneliti melakukan uji independent $t$ test untuk mengetahui perbedaan keterampilan sosial siswa berdasarkan jenis kelamin dan melakukan uji one-way ANOVA untuk mengetahui perbedaan keterampilan sosial siswa berdasarkan jenis hambatan dan tingkat hambatan yang dialaminya. Berdasarkan hasil uji independent t-test, didapatkan bahwa terdapat perbedaan keterampilan sosial yang dimiliki siswa berkebutuhan khusus berdasarkan jenis kelamin, dengan $t(363)=$ $2,11, p=0.035$. Hasil tersebut menunjukkan bahwa siswa laki-laki cenderung menunjukkan keterampilan sosial yang signifikan lebih tinggi dibanding siswa perempuan.

Tabel 4

Gambaran keterampilan sosial siswa $(\mathrm{N}=365)$

\begin{tabular}{lcccc}
\hline $\begin{array}{c}\text { Dimensi keterampilan } \\
\text { sosial }\end{array}$ & $M$ & $S D$ & $\begin{array}{c}\text { Score } \\
\text { Minimum }\end{array}$ & $\begin{array}{c}\text { Score } \\
\text { Maximum }\end{array}$ \\
\hline Komunikasi & 1,85 & 0,52 & 0,00 & 3,00 \\
Kerjasama & 1,91 & 0,59 & 0,00 & 3,00 \\
Asertif & 1,65 & 0,61 & 0,00 & 3,00 \\
Tanggung Jawab & 1,80 & 0,62 & 0,00 & 3,00 \\
Empati & 1,83 & 0,56 & 0,00 & 3,00 \\
Keikutsertaan & 1,87 & 0,54 & 0,00 & 3,00 \\
Kontrol Diri & 1,42 & 0,57 & 0,00 & 3,00 \\
\hline
\end{tabular}


Tabel 5

Korelasi antar dimensi keterlibatan orang tua dan keterampilan sosial siswa

\begin{tabular}{lccccccc}
\hline & Asertif & $\begin{array}{c}\text { Kerja } \\
\text { sama }\end{array}$ & Empati & $\begin{array}{c}\text { Komu- } \\
\text { nikasi }\end{array}$ & $\begin{array}{c}\text { Tanggung } \\
\text { Jawab }\end{array}$ & $\begin{array}{c}\text { Keikut- } \\
\text { sertaan }\end{array}$ & $\begin{array}{c}\text { Kontrol } \\
\text { Diri }\end{array}$ \\
\hline $\begin{array}{l}\text { Keterlibatan Orang Tua } \\
\text { di Sekolah }\end{array}$ & $0,16^{* *}$ & $0,28^{* *}$ & $0,21^{* *}$ & $0,23^{* *}$ & $0,20^{* *}$ & $0,14^{* *}$ & $0,15^{* *}$ \\
$\begin{array}{l}\text { Keterlibatan Orang Tua } \\
\text { di Rumah }\end{array}$ & $0,19^{* *}$ & $0,37^{* *}$ & $0,23^{* *}$ & $0,31^{* *}$ & $0,26^{* *}$ & $0,19^{* *}$ & $0,16^{* *}$ \\
$\begin{array}{l}\text { Hubungan Rumah dan } \\
\text { Sekolah }\end{array}$ & $0,17^{* *}$ & $0,28^{* *}$ & $0,19^{* *}$ & $0,22^{* *}$ & $0,20^{* *}$ & $0,14^{* *}$ & $0,12^{* *}$ \\
\hline
\end{tabular}

Berdasarkan hasil uji one-way ANOVA, didapatkan bahwa tidak terdapat perbedaan keterampilan sosial yang dimiliki siswa berdasarkan jenis hambatan yang dialaminya, dengan $F(12,35)=1,31, p=$ 0,21 ; serta tidak terdapat perbedaan keterampilan sosial yang dimiliki siswa berdasarkan tingkat hambatan yang dialaminya $F(2,36)=0,33, p=0,72$.

\section{Diskusi}

Berdasarkan hasil penelitian, keterlibatan orang tua pada pendidikan siswa berkebutuhan khusus cenderung tinggi, baik pada dimensi keterlibatan orang tua di sekolah, keterlibatan orang tua di rumah, dan hubungan antara sekolah dan rumah. Keterlibatan orang tua di sekolah dan hubungan antara orang tua dan guru cenderung tinggi dikarenakan siswa berkebutuhan khusus cenderung mengalami masalah akademik dan sosial di sekolah. Keterlibatan orang tua dan komunikasi antara orang tua dengan pihak sekolah menjadi hal yang penting, agar siswa ini dapat melakukan penyesuaian diri yang baik di sekolah (AlvarezValdivia, Chavez, Roberts, Becalli-Puerta, Perez-Lujan, and Sanz Martinez, 2012). Keterlibatan orang tua di rumah cenderung tinggi dikarenakan siswa berkebutuhan khusus membutuhkan dukungan yang optimal untuk meningkatkan kemampuan akademik dan tingkah lakunya (McDonnall, Cavenaugh, \& Giesen, 2012).

Berdasarkan hasil penelitian, orang tua lebih cenderung menilai bahwa siswa berkebutuhan khusus memiliki keterampilan sosial yang tinggi. Hasil ini berlainan dengan penelitian terdahulu yang menunjukkan bahwa siswa berkebutuhan khusus yang belajar di sekolah dasar inklusif memiliki keterampilan sosial yang rendah (Macintosh \& Dissanayake, 2006; Frostad \& Pijl, 2007). Orang tua yang menjadi responden penelitian ini cenderung melihat keberadaan anaknya di sekolah inklusif sebagai bagian dari pemenuhan tuntutan untuk memiliki keterampilan sosial. Sebagaimana dinyatakan oleh Chan, Ramey, Ramey, dan Schmitt (2000), terdapat kecenderungan bahwa orang tua tidak ingin anaknya dinilai buruk dimana anggapan tingkah laku anak yang buruk adalah hasil dari pengasuhan orang tua.

Penelitian menunjukkan hasil bahwa keterlibatan orang tua berkorelasi positif dan signifikan dengan keterampilan sosial siswa berkebutuhan khusus. Hasil ini sesuai dengan penelitian Epley (2009), yakni keterlibatan orang tua dalam perencanaan program pendidikan siswa dan keterlibatannya dalam berbagai aktivitas di rumah, dapat meningkatkan keterampilan sosial yang dimiliki anaknya yang berkebutuhan khusus. Selain itu, 
keterlibatan orang tua di sekolah dan hubungan antara orang tua dengan sekolah juga bermanfaat bagi orang tua dalam memahami perkembangan anaknya. Informasi mengenai perkembangan siswa berkebutuhan khusus yang diberikan guru kepada orang tua, akan menjadi dorongan bagi orang tua untuk mengembangkan keterampilan yang berkaitan dengan aktivitas sekolah, termasuk dalam hal keterampilan sosial (Powell et al., 2010).

Keterlibatan orang tua dalam meningkatkan keterampilan sosial siswa berkebutuhan khusus di sekolah dasar inklusif, menjadi lebih penting karena siswa diharapkan mampu untuk menunjukkan keterampilan sosialnya, yang dapat memungkinkannya berinteraksi, bekerja sama dengan teman-teman sebayanya dan juga guru di sekolah (Stright, Gallagher, \& Kelley, 2008). Siswa berkebutuhan khusus yang memililiki keterampilan sosial yang buruk bisa dianggap sebagai siswa yang memiliki ketidakmampuan yang signifikan, dikarenakan siswa ini tidak mampu berinteraksi dengan guru dan teman sebayanya. Oleh karenanya, siswa berkebutuhan khusus sering kali tidak diterima oleh teman sebayanya dan lingkungan sekolahnya (Ballard \& MacDonald, 1998).

Hasil penelitian menunjukkan bahwa keterlibatan orang tua berhubungan secara siginifikan dengan keterampilan sosial siswa berkebutuhan khusus. Akan tetapi, berdasarkan wawancara dengan beberapa guru di beberapa sekolah, siswa berkebutuhan khusus menunjukkan keterampilan sosial yang rendah. Siswa ini cenderung kurang bisa menaati peraturan sekolah dan menunjukkan hambatan dalam bekerja sama dengan teman sebayanya. Tampaknya orang tua dari siswa berkebutuhan khusus yang belajar di sekolah dasar inklusif lebih menekankan aspek akademik dibandingkan keterampilan sosial. Hal ini sesuai dengan apa yang dinyatakan oleh Frederickson, Dunsmuir, Lang, dan Monsen (2004). Di lain pihak, ketika siswa berkebutuhan khusus belajar di sekolah dasar inklusif, orang tua mengharapkan keterampilan sosial siswa berkebutuhan khusus dapat berkembang dengan baik. Mereka juga berharap agar anaknya dapat membangun interaksi dan persahabatan dengan teman-temannya di sekolah. Akan tetapi pada kenyataannya, menempatkan siswa berkebutuhan khusus di sekolah dasar inklusif tidak serta merta bisa meningkatkan keterampilan sosialnya, yang ternyata juga didukung dengan hasil studi dari Koster, Pijl, Nakken, dan Houten (2010).

Beberapa penelitian menunjukkan bahwa faktor sekolah, kelas, dan pengajaran yang diberikan oleh guru dapat memengaruhi perkembangan keterampilan sosial siswa. Demikian juga perbandingan antara jumlah siswa dan guru yang mengajar dalam satu kelas di sekolah (Mashburn et al., 2008). Interaksi antara guru dan siswa serta emotional support yang diberikan oleh guru kepada siswa dapat memengaruhi keterampilan sosial siswanya (Mashburn et al., 2008). Penelitian-penelitian tersebut didukung oleh Milsom dan Glanville (2010) yang menyatakan bahwa guru memiliki peran penting dalam mengembangkan keterampilan sosial siswa berkebutuhan khusus di sekolah dasar inklusif.

Faktor demografi yang diuji dalam penelitian ini adalah jenis kelamin siswa, jenis hambatan, dan tingkat hambatan yang dimiliki siswa. Berdasarkan jenis kelamin, hasil menunjukkan bahwa anak laki-laki cenderung lebih memiliki keterampilan sosial yang baik dibandingkan anak perempuan. Hasil ini bertentangan dengan hasil penelitian Epley (2009) yang 
mengungkapkan bahwa anak perempuan cenderung lebih memiliki keterampilan sosial yang lebih baik dibandingkan anak laki-laki. Hal ini bisa dikarenakan jumlah siswa berkebutuhan khusus laki-laki dalam penelitian ini dua kali lipat lebih banyak dibandingkan siswa berkebutuhan khusus perempuan. Juga orang tua cenderung merasakan perlunya dukungan agar anak laki-laki mereka memiliki keterampilan sosial di sekolah.

Berdasarkan hasil penelitian ini, tidak terdapat perbedaan keterampilan sosial yang dimiliki siswa bila dikaitkan dengan tingkat hambatan yang dialami. Hasil ini sesuai dengan hasil penelitian Gresham dan Elliott (2008) yang menunjukkan bahwa siswa berkebutuhan khusus dengan tingkat hambatan berat cenderung tidak dapat mempelajari dan menunjukkan keterampilan sosial yang diharapkan.

Ternyata jenis hambatan tidak memprediksi keterampilan sosial siswa berkebutuhan khusus yang dinilai oleh orang tua dan guru. Hasil ini bertentangan dengan hasil penelitian Macintosh dan Dissanayake (2006) serta Lane dan kawankawan (2006) yang menunjukkan bahwa jenis hambatan dapat memprediksi keterampilan sosial yang dimiliki siswa berkebutuhan khusus. Hal ini tampaknya dikarenakan penelitian ini mengambil partisipan siswa berkebutuhan khusus yang terdiri dari berbagai macam hambatan, berbeda dengan penelitian Macintosh dan Dissanayake (2006) yang hanya menguji keterampilan sosial pada siswa yang mengalami autis (highfunctioning dan Asperger). Selain itu, menurut hasil penelitian Lane dan kawankawan (2006), siswa berkebutuhan khusus yang mengalami gangguan emosi dan tingkah laku cenderung menunjukkan keterampilan sosial yang rendah. Kebanyakan partisipan dalam penelitian ini merupakan siswa berkebutuhan khusus yang tergolong tunagrahita dan lamban belajar. Meskipun siswa berkebutuhan khusus yang umumnya mengalami gangguan kognitif ini cenderung mempunyai ketidakmampuan sebagaimana yang diharapkan, hampir 50\% partisipan dalam penelitian ini memiliki tingkat hambatan ringan. Siswa yang memiliki tingkat hambatan ringan cenderung dapat melakukan aktivitasnya secara mandiri, sehingga memungkinkannya untuk memiliki interaksi yang baik dengan teman sebayanya (Mangunsong, 2014).

Keterbatasan dari penelitian ini adalah, cara memperoleh data dimana kuesionernya kebanyakan tidak dapat diberikan secara langsung kepada orang tua, melainkan melalui guru di sekolah, sehingga tidak dapat mengamati proses pengisiannya. Juga variasi jenis kebutuhan khusus dan tingkat hambatan yang dimiliki proporsinya kurang seimbang, sehingga tidak dapat dibandingkan untuk melihat apakah ada pengaruh dari kelompok yang terhambat karena masalah kognitif, sensori atau perilaku terhadap keterampilan sosialnya.

\section{Kesimpulan}

Hasil uji korelasi menunjukkan bahwa kedua variabel yang digunakan dalam penelitian ini, yakni keterlibatan orang tua dan keterampilan sosial siswa memiliki hubungan yang signifikan. Keterlibatan orang tua yang tinggi berkaitan dengan keterampilan sosial siswa berkebutuhan khusus yang juga tinggi di sekolah dasar inklusif. Hasil penelitian ini menunjukkan bahwa keterlibatan orang tua dan keterampilan sosial siswa merupakan aspek-aspek yang harus diperhatikan serta ditingkatkan dalam konteks pendidikan inklusif di Indonesia. Selain itu, penelitian 
ini dapat menjadi landasan bagi orang tua untuk perlu lebih terlibat dalam pendidikan anaknya, karena siswa berkebutuhan khusus memiliki tantangan yang lebih besar ketika berada di sekolah dasar inklusif.

\section{Saran}

Penelitian ini merupakan penelitian yang dilakukan dengan desain one-shot study, dimana data diambil hanya satu kali untuk kemudian diolah dan diinterpretasikan sesuai teori. Padahal, konstruk keterlibatan orang tua dan keterampilan sosial merupakan variabel yang dinamis yang dapat berubah seiring bertambahnya usia dan tugas belajar anak. Oleh karenanya, sangat menarik bila penelitian selanjutnya menguji mekanisme hubungan kedua variabel tersebut secara longitudinal.

\section{Kepustakaan}

Aini, Q. (2008). Hubungan antara persepsi dengan interaksi sosial siswa reguler terhadap siswa autis di sekolah inklusi (unpublished undergraduate Thesis). Jakarta: Universitas Islam Negeri Syarif Hidayatullah

Alvarez-Valdivia, I. M., Chavez, K. L., Schneider, B. H., Roberts, J. S., BecalliPuerta, L. E., Perez-Lujan, D., \& SanzMartinez, Y. A. (2012). Parental involvement and the academic achievement and social functioning of Cuban school children. School Psychology International, 34, 313-329.

Ballard, K., \& MacDonald, T. (1998). New Zealand: Inclusive school, inclusive philosophy?. In Booth, T., \& Ainscow, M. From them to us: An international study of inclusion on education. London: Routledge.
Beaton, D. E., Bombardier, C., Guillemin, F., \& Ferraz, M. B. (2000). Guidelines for the process of cross-cultural adaptation of self-report measures. SPINE, 25(24), 3186-3191.

Bennett, K. S., \& Hay, D. A. (2007). The role of family in the development of social skills in children with physical disabilities. International Journal of Disability, Development and Education, 54(4), 381-397. doi: 10.1080/10349 120701654555.

Booth, T., \& Ainscow, M. (2002). Index for inclusion: developing learning and participation in schools. The Centre for Studies on Inclusive Education (CSIE).

Cartledge, G., \& Milburn, J. F. (1995) Teaching social skills to children and youth: Innovative approaches (3rd ed.). Massachusetts: Allyn and Bacon.

Chan, D., Ramey, S., Ramey, C., \& Schmitt, S. (2000). Modeling intraindividual changes in children's social skills at home and at school: A multivariate latent growth approach to understanding between-settings differences in children's social skill development. Multivariate Behavioral Research, 35(3), 365-396.

Dessemontet, R. S., Bless, G., \& Morin, D. (2012). Effects of inclusion on the academic achievement and adaptive behavior of children with intellectual disabilities. Journal of Intellectual Disability Research, 56(6).

Epley, P. H. (2009). Early school performance for students with disabilities: Examining the impact of early childhood special education, parent involvement, and family quality of life (Unpublished Dissertation). Rockhurst University, Kansas.

Fantuzzo, J., Tighe, E., \& Childs, S. (2000). Family involvement questionnaire: A multivariate assessment of family 
participation in early childhood education. Journal of Educational Psychology, 92(2), 367-376.

Flem, A. \& Keller, C. (2000) Inclusion in Norway: A study of ideology in practice. European Journal of Special Needs Education, 15(2), 188-205.

Frederickson, N., Dunsmuir, S., Lang, J., \& Monsen, J. J. (2004). Mainstreamspecial school inclusion partnerships: pupil, parent and teacher perspectives. International Journal of Inclusive Education INT. J. INCLUSIVE, 8(1), 3757. doi: 10.1080/1360311032000159456.

Frostad, P., \& Pijl, S. J. (2007). Does being friendly help in making friends? The relation between the social position and social skills of pupils with special needs in mainstream education. European Journal of Special Needs Education, 22(1), 15-30.

Gresham, F. M., \& Elliot, S. N. (1990). The social skills rating system. Cirle Pines, MN: American Guidance Service.

Gresham, F. M., \& Elliott, S. N. (2008). Social skills improvement system-rating scales. Minneapolis, MN: Pearson Assessments.

Kementerian Pendidikan dan Kebudayaan. (2017). Sekolah Inklusi dan Pembangunan SLB Dukung Pendidikan Inklusi. [Online] Tersedia: http://www. kemdikbud.go.id/main/blog/2017/02/s ekolah-inklusi-danpembangunan-slbdukung-pendidikan-inklusi. (Diakses 11 April 2018).

Koster, M., Pijl, S. J., Nakken, H., \& Van Houten, E. (2010). Social participation of students with special needs in regular primary education in the Netherlands. International Journal of Disability, Development and Education, 57(1), 59-75. doi: 10.1080/ 10349120903537905.
Krull, J., Wilbert, J., \& Henneman, T. (2014). The social and emotional situation of first graders with classroom behavior problems and classroom learning difficulties in inclusive classes. Learning Disabilities: A Contemporary Journal, 12(2).

Lane, K. L., Carter, E. W., Pierson, M. R., \& Glaeser, B. C. (2006). Academic, social, and behavioral characteristics of high school students with emotional disturbance or learning disabilities. Journal of Emotional and Behavioral Disorders, 14, 108-117.

Leyser, Y., \& Kirk, R. (2004). Evaluating Inclusion: an examination of parent views and factors influencing their perspectives. International Journal of Disability, Development and Education, 51(3), 271-285. doi: 10.1080/103491204 2000259233.

Macintosh, K., \& Dissanayake, C. (2006). Social skills and problem behaviours in leeschool aged children with highfunctioning autism and Asperger's disorder. Journal of Autism and Developmental Disorders, 36, 1065-1076. doi: 10.1007/s10803-006-0139-5.

Mangunsong, F. (2014). Psikologi pendidikan anak berkebutuhan khusus (Jilid 1). Depok: Lembaga Pengembangan Sarana Pengukuran dan Pendidikan Psikologi UI (LPSP3 UI).

Mashburn, A. J., Pianta, R. C., Hamre, B. K., Downer, J. T., Barbarin, O. A., Bryant, D., Burchinal, M., ... Early, D. M. (2008). Measures of classroom quality in prekindergarten and children's development of academic, language, and social skills. Child Development, 79(3), 732-749.

McDonnall, M. C., Cavenaugh, B. S., \& Giesen, M. J. (2012). The relationship between parental involvement and 
mathematics achievement for students with visual impairments. Journal of Special Education, 45(4), 204-215.

McWayne, C. M., Fantuzzo, J. W., \& McDermott, P. A. (2004). Preschool competency in context: An investigation of the unique contribution of child competencies to early academic success. Developmental Psychology, 40(4), 633-645. doi: 10.1037/00121649.40.4.633.

Milsom, A., \& Glanville, J. L. (2010). Factors mediating the relationship between social skills and academic grades in a sample of students diagnosed with learning disabilities or emotional disturbance. Remedial and Special Education, 31(4), 241-251.

National Associaton of Special Education Teachers. (2004). Promoting positive social interactions in an inclusion setting for students with learning disabilities. National Association of Special Education Teachers Learning Disabilities. Retrieved from: http://faculty.uml.edu/darcus/01.505/n aset_social_inclusion.pdf.

Nokali, N., Bachman, H., \& Votruba-Drzal, E. (2010). Parent involvement and children's academic and social development in elementary school. Child Development, 81(3), 988-1005.

Odom, S. L., Buysse, V., \& Soukakou, E. (2011). Inclusion for young children with disabilities: A quarter century of research perspectives. Journal of Early Intervention, 23, 344-356.

Peters, S. J. (2007). "Education for all?": A historical analysis of international inclusive education policy and individuals with disabilities. Journal of Disability Policy Studies, 18(2), 98-108.

Powell, D. R., Son, S., File, N., \& San, R. R. (2010). Parent-school relationships and children's academic and social outcomes in public school prekindergarten. Journal of School Psychology, 48(4), 269-292.

Rimm-Kaufman, S. E., Curby, T. W., Grimm, K. J., Brock, L. L., \& Nathanson, L. (2009). The contribution of children's self-regulation and classroom quality to children's adaptive behaviors in the kindergarten class-room. Developmental Psychology, 45, 958-972.

Rotheram-Fuller, E., Kasari, C., Chamberlain, B., \& Locke, J. (2010). Social involvement of children with autism spectrum disorders in elementary school classrooms. Journal of Child Psychology and Psychiatry, and Allied Disciplines, 51(11), 1227-1234.

Sanders, M. R., \& Morawska, A. (2010). Family background questionnaire. Brisbane: Parenting and Family Supports Centre.

Stright, A. D., Gallagher, K. C., \& Kelley, K. (2008). Infant temperament moderates relations between maternal parenting in early childhood and children adjustment in first grade. Child Development, 79(1), 186-200.

Szumski, G., \& Karwowski., M. (2014). Psychosocial functioning and school achievement of children with mild intellectual disability in polish special, integrative, and mainstream. Journal of Policy and Practice in Intellectual Disabilities, 11(2), 99-108. 